\title{
Reducing microzones and sulfide production in marine snow
}

\author{
Alan L. Shanks, Margaret L. Reeder \\ University of Charleston, Grice Marine Biological Laboratory, 205 Fort Johnson, Charleston, South Carolina 29412, USA
}

\begin{abstract}
Using tetrazolium salts we tested the hypothesis that reducing microzones can form within detrital aggregates (i.e. marine snow). Even when the ambient waters were well oxygenated, patches of reduced tetrazolium salts were found in marine snow indicating that strongly reducing microzones were present in these aggregates. Further, in both laboratory-made and field-collected marine snow we found measurable amounts of sulfide. Sulfide was present in marine snow on 9 out of 10 sample dates and the sulfide concentration within marine snow ranged from 1.3 to $25 \mu \mathrm{mol} \mathrm{Sl^{-1 }}$ On only 1 out of 10 dates was sulfide detected in the oxygenated waters surrounding the aggregates. The sulfide in the marine snow was probably produced by anaerobic microbes in the reducing microzones in the marine snow. Our data suggest that the paradoxical production of sulfide in aerobic water columns is probably due to production within anoxic microzones within marine snow.
\end{abstract}

\section{INTRODUCTION}

Microbial production of methane and sulfide only occurs in anoxic environments. Paradoxically, in the oxygenated waters of the ocean microbes produce both chemicals (Brooks et al. 1981, Burke et al. 1983, Cutter \& Krahforst 1988). How can these microbial reactions that are dependent on a reducing environment occur in oxygenated waters? This paradox might be resolved if anoxic microzones form in detrital aggregates suspended in the aerobic water column.

Macroscopic detrital aggregates (marine snow) are ubiquitous in the world's oceans (Alldredge \& Silver 1988). Alldredge \& Cohen (1987), using oxygen microelectrodes, found that the oxygen concentration in marine snow in the dark could drop as low as $46 \%$ below the surrounding ambient oxygen concentration. Alldredge \& Cohen (1987) did not, however, find anoxic zones in the aggregates they investigated.

They did not observe anoxic conditions, perhaps, because their oxygen measurements were made at $100 \mu \mathrm{m}$ intervals and in seawater with a high ambient oxygen concentration. Researchers working in benthic environments have frequently found anoxic microzones scattered throughout aerobic sediments (Jørgensen
1977). Similar microzones might form in marine snow. Because of the potentially small size of the anoxic zones, the sampling regime of Alldredge \& Cohen (1987) may have inadvertently missed anoxic microzones.

Near the ocean's surface, marine snow is suspended in water with a high ambient oxygen concentration, but as the aggregates sink they can enter deeper waters with quite low oxygen concentrations (e.g. $<1 \mathrm{mg}$ $\mathrm{I}^{-1}$ ), the oxygen minimum layer (Sverdrup et al. 1942). In the oxygen minimum layer, because of the lower ambient oxygen concentration, there will be a reduced flux of oxygen into aggregates. Under these conditions the microbial community in the marine snow might be able to reduce the oxygen concentration in an aggregate to zero. We used laboratory-made artificial marine snow and tetrazolium salts to investigate the hypothesis that reducing microzones can form in aggregates.

\section{METHODS}

Tetrazolium salts are water-soluble under oxidized conditions, but form insoluble colored formazan crystals when reduced (Paerl 1984). We used the tetra- 
zolium salts INT [2-(4-iodophenyl)-3-(4-nitrophenyl) -5-phenyltetrazolium chloride] and TV (3-naphthyl2,5-diphenyl-2H-tetrazolium chloride), which are reduced at an Eh of +50 and $-290 \mathrm{mV}$ respectively,

Laboratory-made artificial marine snow was generated following the methods of Shanks \& Edmondson (1989). Cylindrical tanks $(14 \mathrm{~cm}$ diameter $\times 6.5 \mathrm{~cm}$ deep) of unfiltered seawater from Charleston Harbor Estuary, South Carolina, USA $\left(79^{\circ} 55^{\prime} \mathrm{W}, 32^{\circ} 45^{\prime} \mathrm{N}\right)$, were rotated on a roller table until the particles in the seawater formed aggregates (about 0.5 to $1.5 \mathrm{~h}$ ). A previous study demonstrated that these artificial aggregates are a good biological model of natural marine snow (Shanks \& Edmondson 1989). The marine snow was formed and maintained in the laboratory at room temperature $\left(20^{\circ} \mathrm{C}\right)$ and under room lights. Before sampling marine snow a photograph was taken of each tank while it was rolling on the roller table. These photographs were used to determine the size and abundance of aggregates in the tanks. Prior to the formation of marine snow, nitrogen gas was bubbled through some water samples to reduce the ambient oxygen concentration.

Experiments with the tetrazolium salts began in October 1991. One or two $\mathrm{ml}$ of a $1 \%$ solution (weight/volume) of INT and/or TV was added to each tank. The dyes were allowed to react with the marine snow for anywhere from 3 to $24 \mathrm{~h}$. At intervals (one to several hours) after the addition of the dye, samples of marine snow (aggregates of 1 to $5 \mathrm{~mm}$ diameter) were removed from the tanks with a pipette, placed on a slide, and inspected under a compound microscope.

Given that reducing microzones may be present in aggregates, we investigated the possibility that the byproducts of anaerobic metabolism were present in aggregates. We tested this hypothesis by measuring the concentration of sulfide in marine snow made in the laboratory and that collected in the field. We also measured the concentration of sulfide in the water surrounding the marine snow. These experiments were done in April and May 1992.

Artificial marine snow was made in the laboratory and sampled when it was about $10 \mathrm{~h}$ old. Using a $3 \mathrm{ml}$ syringe inserted through a serum cap. 10 to 20 aggregates were collected from each rotating tank. About 30 $\mathrm{ml}$ of water surrounding the marine snow was sampled with a $50 \mathrm{ml}$ syringe. On 13 and 21 April, surrounding water samples were collected as the tanks rotated on the roller table. It was impossible to avoid inadvertently collecting some aggregates during this sampling procedure. Subsequently, the tanks were removed from the roller table and allowed to stand until the marine snow had sunk to the bottom of the tank (this took about $5 \mathrm{~min}$ ) at which time the surrounding water was sampled. Marine snow and surrounding water samples were immediately injected with the reagents used in the sulfide analysis.

Field sampling of marine snow took place in the waters around the San Juan Islands, Washington, USA $\left(48^{\circ} 40^{\prime} \mathrm{N}, 123^{\circ} 0^{\prime} \mathrm{W}\right)$, in August 1992. In the field, photographs were taken to determine the average size and abundance of marine snow (Shanks \& Edmondson 1990). Five replicate samples of about $30 \mathrm{ml}$ of water surrounding marine snow and $30 \mathrm{ml}$ of marine snow (100 aggregates per sample) were collected in syringes (Shanks \& Edmondson 1990) at about $8 \mathrm{~m}$ depth. Approximately $1 \mathrm{~h}$ elapsed between sample collection and the addition of reagents.

The sulfide analysis used was a modification of Cline's (1969). This technique for measuring sulfide in seawater uses a $10 \mathrm{~cm}$ path-length cell and is considered to be accurate down to a concentration of $1 \mu \mathrm{mol}$ $\mathrm{S} \mathrm{I}^{-1}$. We found, however, that with care we could use a $1 \mathrm{~cm}$ path-length cell and that the useful range of this technique is down to a concentration of $0.2 \mu \mathrm{mol} \mathrm{S} \mathrm{I}{ }^{-1}$. Between 0.2 and $3.0 \mu \mathrm{mol} \mathrm{Sl^{-1 }}$, we found a linear relationship between the concentration of sulfide and absorbance $(\mathrm{n}=7, \mathrm{r}=0.9978, \mathrm{p}<0.01)$. Marine snow and surrounding water samples were analyzed using 1 and $10 \mathrm{~cm}$ path-length cells respectively. All samples were filtered through $0.45 \mu \mathrm{m}$ Millipore filters prior to reading on the spectrophotometer.

\section{RESULTS}

Over a wide range of ambient oxygen concentrations (0.6 to $10.6 \mathrm{mg} \mathrm{O}_{2} \mathrm{I}^{-i}$ ) the tetrazolium salts INT and TV were reduced in the laboratory-made marine snow (Table 1). Several hours after the addition of tetrazolium saits formazan crystals formed within many, but not all, of the aggregates in a tank. Reduced tetrazolium salts were usually found in tiny patches (i.e. 100 to $300 \mu \mathrm{m}$ diameter) scattered throughout the aggregates. Often the patches of reduced dye were inside pieces of detritus, especially diatom frustules.

INT is reduced at a lower Eh than TV (Paerl 1984). INT tended to be reduced more quickly and produced larger patches of formazan crystals than TV. Patches of reduced TV tended to be more frequently found inside detrital particles. As anticipated, reduced patches of INT and TV tended to be more abundant in marine snow in tanks with low ambient oxygen concentrations. These observations indicate that highly reducing and probably anoxic microzones were present in laboratory-made marine snow.

Throughout the observations of sulfide in laboratorymade marine snow, oxygen did not drop below $6.8 \mathrm{mg}$ $\mathrm{O}_{2} 1^{-1} \mathrm{~S}$ (Table 2). Sulfide was detectable in most of the marine snow samples (Table 2), but decreased steadily 
were well above the reagent and turbidity blanks), but concentrations were slightly below the usable range of the modified sulfide technique $\left(0.2 \mu \mathrm{m} \mathrm{S} 1^{-1}\right)$. Sulfide concentrations in these samples were estimated by assuming that the linear relationship between absorbance and concentration held at concentrations below the usable range of the technique. The concentration of sulfide within the aggregates was around 3.7 and

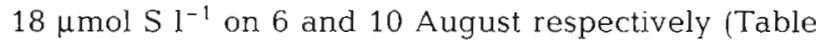
2). Despite the high ambient oxygen concentration (almost $9 \mathrm{mg} \mathrm{O} \mathrm{O}_{2} \mathrm{l}^{-1}$ ), sulfide was present in the natural marine snow.

\section{DISCUSSION}

Our results suggest that highly reducing microzones can exist in marine snow. These microzones formed even in aggregates suspended in well oxygenated waters. Sulfide was present in marine snow samples from 8 of 9 laboratory experiments and on both dates on which field samples were collected. Sulfide was detected only in those surrounding water samples which had been contaminated with marine snow. Sulfide present in the aggregates was probably the result of the metabolism of anaerobic microbes in reducing microzones in the marine snow.

We found it surprising that following the addition of the tetrazolium salts it took at least several hours before we observed formazan crystals forming within the marine snow. The aggregates in the roller tanks, like those in the field, were falling through the water. Thus, there was advection of water around as well as through the aggregates (Logan \& Alldredge 1989). We expected advection to fairly rapidly deliver the tetrazolium salts to reducing zones. The long delay between the addition of the tetrazolium salts and the formation of formazan crystals suggests that the tetrazolium salts were not delivered to the reducing microzones via advection. Most of the reduced tetrazolium salts were found in microzones bounded by detritus. For example, frequently formazan crystals were found within diatom frustules. The physical structure provided by the detritus could prevent the advection and greatly slow the diffusion of material in or out of a microzone. The formation of reducing microzones within marine snow is, in fact, probably dependent upon the reduced flux of oxygen into the microzone which is caused by the physical structure of the detritus.

Initially, sulfide concentrations within the laboratory-made marine snow were around $25 \mu \mathrm{mol} \mathrm{S}{ }^{-1}$, but by mid-May sulfide had dropped below $1.5 \mu \mathrm{mol} \mathrm{S} \mathrm{l}{ }^{-1}$ and by 27 May sulfide was undetectable. Over this period there were no systematic changes in the size, abundance, or appearance of the laboratory-made marine snow. The reason for the steady decline of sulfide in the marine snow is unknown, but may be related to the seasonal warming of the coastal waters with concomitant changes in the water column microbial population.

Knowing the number of aggregates in the tanks or per liter in the field, along with the average concentration of sulfide in the marine snow, we calculated the overall or total sulfide concentration (i.e. the amount of sulfide in a liter of water contributed by the marine snow plus the surrounding water). In the laboratory, on those days when sulfide was present in the aggregates, the total concentration of sulfide in the experimental tanks ranged from 0.1 to $16 \mathrm{nmol} \mathrm{S}^{-1}$. In the field samples collected around the San Juan Islands, calculated sulfide concentrations were 0.08 and $0.53 \mathrm{nmol} \mathrm{S} \mathrm{l}^{-1}$. Our observations suggest that all of the sulfide in the water column could be due to that present in just the marine snow.

Cutter \& Krahforst (1988), employing a far more sensitive technique, measured the concentration of sulfide in bulk water samples from the western Atlantic Ocean. These samples were collected with standard oceanographic sample bottles and would have contained disrupted marine snow (Trent et al. 1978) mixed with surrounding water. The highest sulfide concentration they observed $\left(1.1 \mathrm{nmol} \mathrm{l}^{-1}\right)$ was found in summer near the mouth of the Chesapeake Bay. On a cross-shelf transect offshore from Charleston, South Carolina, sulfide was highest near shore. The total sulfide concentrations in two of our laboratory samples were significantly higher (5 to $10 \times$ higher) than the highest values reported by Cutter \& Krahforst (1988), but in the remainder of our laboratory samples the total sulfide concentrations were similar in magnitude to theirs. The total sulfide concentration we calculated for the field samples were also similar to those found by Cutter \& Krahforst (1988).

Much of the downward flux of particles through the ocean is via marine snow (Shanks \& Trent 1980, Asper 1987, Walsh \& Gardner 1992, reviewed in Fowler \& Knauer 1986). Sulfide present in marine snow may form insoluble complexes with a variety of metals (e.g. CuS; Dyrssen 1988). Complexed metals adsorbed onto the marine snow can be rapidly transported downward with the sinking aggregate (Cowen \& Silver 1984). We predict that the removal of dissolved metals from the water column via this mechanism would be highest where marine snow is abundant (e.g. the surface waters or within an estuary) and/or where marine snow is producing an abundance of sulfide (e.g. perhaps within the oxygen minimum layer). The concentration of some metals dissolved in seawater may be controlled by the chemical reactions occurring in marine snow. 
The presence of reducing microzones apparently capable of producing sulfide suggests that there were communities of anaerobic microbes within the marine snow we sampled. We predict that fermenters and sulfate-reducers will both be found in marine snow. When the ambient oxygen concentration in the water column is low (e.g. within the oxygen minimum layer) the reduced flux of oxygen into aggregates may lead to the formation of microzones within the aggregates which can support methanogens. Methane produced in the water column may originate in marine snow.

Inside an aggregate, reducing microzones were found immediately adjacent to oxic zones. The byproducts of anaerobic decomposition $\left(\mathrm{CH}_{4}, \mathrm{H}_{2} \mathrm{~S}, \mathrm{H}_{2}\right.$, etc.) produced in the microzone could diffuse into the surrounding oxic zones. The energy from the oxidation of these byproducts may fuel bacterial chemolithotrophy. Karl et al. (1984) observed bacterial chemolithotrophy associated with sinking particles. They suggested that the chemolithotrophy might have occurred within large particles. The data presented here suggest that these hypothesized large particles may have been marine snow.

Acknowledgements. This research was supported by NSF Grant No. OCE-9017807 and a Faculty Research and Development Grant from the University of Charleston, South Carolina. Assistance was provided by K. del Carmen and F. Brigman. This is contribution No. 110 from the Grice Marine Biological Laboratory, University of Charleston, South Carolina.

\section{LITERATURE CITED}

Alldredge, A. L., Cohen, Y. (1987). Can microscale chemical patches persist in the Sea? Microelectrode study of marine snow, fecal pellets. Science 235: 689-691

Alldredge, A. L., Silver, M. (1988). Characteristics, dynamics and significance of marine snow. Prog. Oceanogr. 20: $41-82$

Asper, V. L. (1987). Measuring the flux and sinking speed of marine snow aggregates. Deep Sea Res. 34: 1-17

Brooks, J. M., Reid, D. F., Bernard. B. B. (1981). Methane in the upper water column of the Northwestern Gulf of Mexico. J. geophys. Res. 86: 11029-11040

Burke, R. A. Jr, Reid, D. F., Brooks, J. M., Lavoie, D. M. (1983). Upper water column methane geochemistry in the eastern tropical North Pacific. Limnol. Oceanogr. 28: 19-32

Cline, J. D. (1969). Spectrophotometric determination of hydrogen sulfide in natural waters. Limnol. Oceanogr. 14: $454-458$

Cowen, J. P., Silver, M. W. (1984). The association of iron and manganese with bacteria on marine macropaticulate material. Science 224: 1340-1342

Cutter, G. A., Krahforst, C. F. (1988). Sulfide in surface waters of the western Atlantic Ocean. Geophys. Res. Lett. 15: $1393-1396$

Dyrssen, D. (1988). Sulphide complexation in surface seawater. Mar. Chem. 24:143-153

Fowler, S. W., Knauer, G. A. (1986). Role of large particles in the transport of elements and organic compounds through the oceanic water column. Prog. Oceanogr. 16:147-194

Jørgensen, B. B. (1977). Bacterial sulfate reduction within reduced microniches of oxidized marine sediments. Mar. Biol. 41: 7-17

Karl, D. M., Knauer, G. A., Martin, J. H., Ward, B. B. (1984). Bacterial chemolithotrophy in the ocean is associated with sinking particles. Nature 309: 54-56

Logan, B. E., Alldredge, A. L. (1989). Potential for increased nutrient uptake by flocculating diatoms. Mar. Biol. 101: $443-450$

Paerl, H. W. (1984). Alteration of microbial metabolic activities in association with detritus. Bull mar. Sci. 35: $393-408$

Shanks, A. L., Edmondson, E. W. (1989). Laboratory-made artificial marine snow: a biological model of the real thing Mar. Biol. 101: 463-470.

Shanks, A. L., Edmondson, E. W. (1990). The vertical flux of metazoans (holoplankton, meiofauna, and larval invertebrates) due to their association with marine snow. Limnol. Oceanogr 35: 455-463

Shanks, A. L., Trent, J. D. (1980). Marine snow: sinking rates and potential role in vertical flux. Deep Sea Res. 27 : $137-143$

Sverdrup, H. U., Johnson, M. W., Fleming, R. H. (1942). The oceans. Prentice-Hall Inc., Englewood Cliffs

Trent, J. D., Shanks, A. L., Silver. M.W. (1978). In situ and laboratory measurements on macroscopic aggregates in Monterey Bay, California. Limnol. Oceanogr. 23: 626-635

Walsh, I. D., Gardner, W. D. (1992). A comparison of aggregate profiles with sediment trap fluxes. Deep Sea Res. 39: $1817-1834$

Manuscript first received: December 17, 1992

Revised version accepted: February 17, 1993 